\title{
Prevalence of cardiovascular risk factors (CRF) and metabolic syndrome (MS) in a cohort of HIV-infected patients in southern Spain. PREGO study

\author{
M Gallego1, F Oñate ${ }^{2}$, A del Arco ${ }^{3}$, J Roldan4, M Grana ${ }^{5}$, R Palacios*1 and \\ J Santos ${ }^{1}$
}

Address: ${ }^{1}$ Hosp. Virgen de la Victoria, Malaga, Spain, ${ }^{2}$ Hosp. Carlos Haya, Malaga, Spain, ${ }^{3}$ Hosp. Costa del Sol, Marbella, Spain, ${ }^{4}$ Hosp. de Antequera, Antequera, Spain and ${ }^{5}$ Hosp. de la Serrania, Ronda, Spain

* Corresponding author

\author{
from Ninth International Congress on Drug Therapy in HIV Infection \\ Glasgow, UK. 9-13 November 2008 \\ Published: 10 November 2008 \\ Journal of the International AIDS Society 2008, I I (SuppI I):PI02 doi:I0.II86/I758-2652-I I-SI-PI02
}

This abstract is available from: http://www.jiasociety.org/content/I I/SI/PI02

(c) 2008 Gallego et al; licensee BioMed Central Ltd.

\section{Purpose of the study}

To determine the prevalence of CRF and MS in an HIVinfected population, to analyse the risk factors for the development of MS, and to estimate the cardiovascular risk (CVR) at 10 years.

\section{Methods}

Multicenter, cross-sectional study of all outpatients attended in five hospitals in southern Spain from March 2007 - August 2007. Demographic features, blood pressure, tobacco use, lipid profile, diabetes mellitus (DM), personal and family history of coronary heart disease (CHD) were collected. MS was diagnosed according to NCEP. CVR: Framingham score. High CVR: $>10 \%$ at 10 years. Statistics program: SPSS.

\section{Summary of results}

1,155 patients were included; mean age 44 (39-49) years, CD4 count $544(336-711)$ cells $/ \mu \mathrm{l}$, and $86 \%$ on ART (85.5\% with $\mathrm{VL}<50 \mathrm{cop} / \mathrm{mL}$ ). CRF (\%): male 76 , smokers 59, family history of CHD 10.6, hypertension (HT) 10.6, DM 9.4, prior CHD 3.5. A total of 155 (14.3\%) patients fit the criteria of MS: hypertriglyceridemia (HTG) 88.3, low HDL-C levels 78.7, HT 61.9, hyperglycaemia 60.6, and abdominal obesity $41.2 \%$. Use of lipid-lowering drugs ( 24.5 vs. $11.3 \%, \mathrm{p}<0.0001)$, antidiabetics ( 18.0 vs. $1.7 \%$, $\mathrm{p}<0.0001)$, antihypertensives $(21.2$ vs. $5.8 \%$, p < $0.0001)$, and anti-aggregants ( 7.7 vs. $3.6, \mathrm{p}<0.02)$ were more common in cases with MS. MS was present in $15.5 \%$ of patients on PI and $13.7 \%$ on ITINAN (ns); HTG and low HDL-C were more frequent in subjects on PI ( 50.4 vs. $34.9 \%$ and 52.1 vs. $31.6 \%$; $<0.0001$, respectively), and HT and hyperglycaemia in those on NNRTI (26.8 vs. $17.5 \%$, and 20.1 vs. $14.0 \%$; $\mathrm{p}=0.001$, respectively). Age was the only factor associated with MS in multivariate analysis (OR 4.7; CI 95\% 4.6-4.8, for each 5 years more). The mean global CVR at 10 years was $6.4 \%$ (IQR: $1-9$ ), higher in cases with MS (10.9 vs. $5.6 \%, \mathrm{p}<0.0001)$, and similar in PI and NNRTI groups (6.7 vs 6.6\%; ns).

\section{Conclusion}

Tobacco use was the most frequent CRF. In this cohort, the prevalence of MS was lower than in others, and similar to that in general Spanish population, but with a different distribution of its components, predominating HTG and low HDL-C levels. Although the prevalence of MS and mean CVR were similar among patients on PI and those on NNRTI, lipid abnormalities were more frequent with PI, and HT and hyperglycaemia with NNRTI. MS was not associated with any HIV-specific factors, but only with age.

\section{References}

I. Alegría E, et al:: Prevalence of Metabolic Syndrome in the Spanish Working Population: MESYAS Registry. Rev Esp Cardiol 2005, 58:797-806. 
2. Jericó C, et al:: Metabolic syndrome among HIV-infected patients. Diabetes Care 2005, 28: I44-149.

Publish with Bio Med Central and every scientist can read your work free of charge

"BioMed Central will be the most significant development for disseminating the results of biomedical research in our lifetime." Sir Paul Nurse, Cancer Research UK

Your research papers will be:

- available free of charge to the entire biomedical community

- peer reviewed and published immediately upon acceptance

- cited in PubMed and archived on PubMed Central

- yours - you keep the copyright

Submit your manuscript here:

http://www.biomedcentral.com/info/publishing_adv.asp 